\title{
Supporting academic middle managers in Higher Education: do we care?
}

Article

Accepted Version

Floyd, A. (2016) Supporting academic middle managers in Higher Education: do we care? Higher Education Policy, 29 (2). pp. 167-183. ISSN 1740-3863 doi:

https://doi.org/10.1057/hep.2015.11 Available at https://centaur.reading.ac.uk/69428/

It is advisable to refer to the publisher's version if you intend to cite from the work. See Guidance on citing.

Published version at: http://oro.open.ac.uk/43819/

To link to this article DOI: http://dx.doi.org/10.1057/hep.2015.11

Publisher: International Association of Universities

All outputs in CentAUR are protected by Intellectual Property Rights law, including copyright law. Copyright and IPR is retained by the creators or other copyright holders. Terms and conditions for use of this material are defined in the End User Agreement.

\section{www.reading.ac.uk/centaur}

\section{CentAUR}

Central Archive at the University of Reading

Reading's research outputs online 


\title{
Supporting Academic Middle Managers in Higher Education: Do We Care?
}

\begin{abstract}
In the current higher education environment, the need to develop and support good leaders and managers could hardly be more pressing. Yet, research on how academic middle managers are supported in their roles is surprisingly sparse. The purpose of this paper is to address this perceived gap in the literature by reporting on the findings from two separate, but related, research projects investigating the role of the academic middle manager in two culturally different English universities, specifically to examine the support that such leaders have received in relation to taking on and adapting to this increasingly challenging role. By drawing on semi-structured interviews with 28 academic middle managers from one pre and one post 1992 university, the paper argues that we need to provide more support and individually tailored training for today's middle managers so that the best may become the sector's effective senior leaders of tomorrow.
\end{abstract}

Keywords: academic middle managers; organisational culture; leadership development

\section{Introduction}

In the UK and elsewhere, universities continue to react to the demands of increasingly performative systems of accountability (Kolsaker 2008) reflected in such activities as internal and external quality assurance procedures, institutional and national student surveys, research assessment exercises, and national and international published league tables. At the same time, the nature and purpose of higher education (HE) is being contested with institutions coming under growing governmental pressure to prepare graduates for the world of work (Trede et al. 2011) even though it is acknowledged that an artificial dichotomy between liberal education versus vocational education is an 
over-simplistic and unhelpful view of the multi-faceted purposes of HE (Carr 2009). Furthermore, HE institutions are increasingly becoming international in their outlooks (Parsons and Fidler 2005) as they strive to compete in a global HE market.

In such a complex and shifting environment, the need to develop and support good leaders and managers in the sector can hardly be more pressing, especially as there has been recent concern that universities may not be able to respond successfully to these rapidly changing pressures (Kezar et al. 2011). This need is arguably most crucial at the level of academic middle manager (defined here as a department leader or equivalent), as it is within the department where the majority of day to day decision making takes place in relation to teaching and research (Bryman 2009). However, all too often academics assume the role of department head with little or no training (Gmelch 2004).

Given the importance of leadership development for academic middle managers, it is surprising to note that there appears to be very little published research looking specifically at this issue (Gmelch and Miskin 2011) and indeed looking at leadership effectiveness in universities in general (Bryman 2009). Nevertheless, there has been recent research in the UK exploring the changing nature of academic leadership and management in universities as a whole (see Bolden et al. 2012; Deem et al. 2007); departmental leadership of teaching in research-intensive institutions (see Gibbs et al. 2009); and a number of studies exploring the role of the academic middle manager in general. This previous work suggests that these managers require different values and knowledge when they move into the role (Bolton 2000; Knight and Trowler 2001) and that they can struggle to balance their managerial and academic tasks (Smith 2002; 2005). They can also feel as if they are "stuck in the middle" between organisational goals and expectations and those of the staff they lead (Bryman and Lilley 2009, p. 
340), with the increasing pressures of New Public Management placing them "in a pivotal role between central management predilections and academic values and control" (Meek et al. 2010, p. 2). However, in a large ESRC funded study examining the extent to which New Managerialism had permeated the management of UK Universities, Deem et al. (2000) found that only one third of academics who became middle managers received any formal training in leadership and management, and few felt they received enough feedback on their management role. As Johnson (2002, p. 42) reports in a related paper, "At the time of appointment, the majority of HoDs [Head of Department] had received little formal training or preparation, or felt that the training they received was inadequate.”

The purpose of this article, therefore, is to build on this previous work and address the perceived gap in the literature specifically around HE departmental leadership development in the UK by reporting on the findings from two separate, but related, research projects investigating the role of the academic middle manager in two culturally different English universities. The article draws on semi-structured interviews with 28 academic middle managers from one research led and one teaching led university to examine the support that such leaders have received in relation to taking on and adapting to this increasingly challenging leadership position (Floyd and Dimmock 2011). By comparing and contrasting in-depth case study data from two different types of universities, and adopting an analytical framework based on the concept of organisational culture, the article aims to provide an important and original contribution to knowledge.

The two key research questions (RQs) addressed here are: 
RQ1. What training and role preparation have academics who become department heads in two contrasting UK Universities had?

RQ2. How should they be supported in their roles in the future?

Following this introduction, the article is arranged over four sections. First, I outline the theoretical framework underpinning the article. Next, I discuss the methodological choices that were made during the studies and give context to the case study institutions. Then, I discuss the key findings and finally conclude by discussing the implications of these findings for practice and research. This article presupposes that effective middle management development is essential for the future success of our higher education system in these days of global uncertainty.

\section{Theoretical framework}

\section{The changing nature of academic leadership and management}

As international governments try to "compete" within a globalised HE market (Nokkala and Bladh 2014), alongside the fact that higher education and specialized technical knowledge are now perceived as economic commodities in their own rights, the HE sector is now seen as a crucial site of focus for a country's economic success (Shields 2013). Viewing HE from a purely economic perspective, increasingly underpinned by neo-liberalist ideologies (that increased competition improves performance) and notions of New Managerialism (that increasing accountability and efficiency procedures through measurable performance indicators improves performance), has irrevocably changed the structure of the HE system worldwide (Hill and Kumar 2009). In addition, Nagy (2011) asserts that these changes have led to a large increase in student numbers without the necessary increase in academic staff numbers, with the consequence being substantial, increased pressure on academic workloads. Furthermore, it has been 
claimed that these changes are affecting the power relations between the State, universities and academic staff (Kolsaker 2008) and thus the leadership and management practices of individual HE institutions.

The argument put forward by these critics is that academic leadership and management practices and their underpinning value systems have changed from those based on traditional collegial ideals to ones dominated by business-like, market driven principles (de Boer and Goedegebuure 2009): Vice Chancellors have become more like chief executives; Senior Management Teams have emerged consisting of both senior academic and administrative staff (from perceived key areas such as finance and marketing); while department heads are increasingly seen as managers rather than academic leaders, as they shoulder greater accountability for budgets and resource allocation - all measured against centrally set performance indicators (Henkel 2002).

These changes have caused a problem for academics who take on leadership positions, especially as they typically enter the profession subscribing to strongly held core values linked to helping people, wanting to develop deep subject specific knowledge, and professional autonomy (Beck and Young 2005; Floyd 2012). How, then, are academics who take on these roles supported in dealing with what Winter (2009) has termed the identity schism between 'academic managers and 'managed academics' with academic managers being "perceived as 'different' to academics in terms of value frameworks and, thus, their professional identities" (Floyd 2013, p. 92).

Against this complex and ever-shifting contextual backdrop, individual institutions and departments are each responding to these changes in different ways, depending on their stated purpose and unique circumstances. To understand these differences, the concept of organisational culture will now be explored. 


\section{Organisational culture}

Organisational culture has been widely used as an "instrument of analysis" by researchers over the last few decades (Silver 2003, p. 157) with Alvesson (2002, p. 1) suggesting that it is "one of the major issues in academic research and education". It has been defined as "a system of shared values and beliefs that interact with an organisation's people, organizational structures, and control systems to produce behavioural norms" (Owens and Valesky 2011, p. 141). Viewed this way, organisational culture can be seen as a way for senior managers to control workers through socialisation processes which ensure that employees confirm to espoused organisational values and behaviours. Viewing organisational culture through this lens has implications for organisational staff induction and subsequent training and development programmes. However, in his seminal text on organisational culture and leadership, Schein (1985, p. 14) argues that the concept is extremely complex and made up of different levels which "need to be carefully distinguished to avoid conceptual confusion". His framework suggests that organisational culture is made up of three hierarchical levels, namely, level 1: artifacts and creations (the organization's visible and audible behavior patterns), level 2: the organization's values (espoused by the leaders but confirmed only by social consensus), and level 3: the basic underlying assumptions of the organization (below the conscious level of artifacts and what people espouse).

Additionally, it has recently been argued that in order to understand contemporary organisational cultures, it is necessary to view these cultures through a temporal lens and explore what historical events, at both a local and more universal level, have influenced the current organisational climate; thus, organisational culture is seen as a dynamic, ever changing social process over time, constantly being shaped and 
re-shaped through micro and macro level individual and group behaviours (Staber 2013). Furthermore, within higher education, it has been claimed that, "the core beliefs and motivations of faculty are central to the organizational culture of the university..." (Shaw et al. 2013, p. 991).

While this may be so, the notion of organisational culture as a unified concept is contested because that culture is not necessarily shared throughout the whole institution: different working communities, often sub-groups, can have their own distinctive cultures which are linked to shared values held by that sub group (Alvesson 2002). Importantly for this article, and in line with Alvesson's views, McAleer and McHugh (1994) argue that the organisational culture of a university is customized at the department level. Indeed, Trowler (2008, p. 15) goes a step further and argues that university cultures are not only customized at departmental level but are "...generated and sustained at the level of the workgroup within departments..." (author's emphasis). Thus, it is the university department that "is the central locus of cultural enactment and, importantly, construction in universities which are, inevitably, extremely culturally complex organisations" (Knight and Trowler 2000, p. 69). Consequently, conceptually, organisational culture moves from being seen as a controlling mechanism owned by senior managers to something that is initiated and influenced more from academics on the ground. It is this thinking that helps make sense of the data presented in this article.

The next section provides the institutional context within which both studies were conducted and outlines the methods used.

\section{Context and method}

\section{Study 1 - Hillside University}

The first study was undertaken at Hillside University, a large, modern teaching-led 
university situated in the south of England which has its historical roots as a technical college. Hillside University has about 18,000 students and describes itself as having an excellent reputation for teaching with strong links to industry. There has been a shift in recent years to try to increase the research culture of the institution, which is currently quite strong with certain subject areas performing very well in the 2014 UK Research Excellence Framework. Hillside is organised over a number of academic schools with each school having a number of department heads in place. Department heads are recruited through internal (and sometimes external) advertising, with each post being permanent and carrying a promotion (normally to the position of Principal Lecturer or equivalent) and associated financial reward.

\section{Study 2 - Oakbank University}

The second study was undertaken at Oakbank University, a research-led university situated in the south of England. It has more than 15,000 students and is organised into faculties consisting of a number of different departments. In contrast to Hillside, typically the role of department head is not advertised but is rotated after a period of three or four years. In further contrast to Hillside, individuals who take on the role are paid a small annual fee, but the post does not attract a formal promotion.

The next section outlines the methods used in both studies.

\section{Data collection}

In each study, I adopted the interpretive paradigm which is based on the assumption that "social reality is constructed by the individuals who participate in it" (Gall et al. 2007, p. 21). After gaining ethical approval, in both studies theoretical sampling (Gomm 2009) was used to identify participants where the aim was to refine ideas rather than increase sample size. At Hillside, I interviewed 8 male and 9 female middle leaders 
while at Oakbank I interviewed 9 male and 2 female leaders. The differences in sample size and gender breakdown in each study reflect the proportion of department heads at each institution. To ensure anonymity, both the institution names have been changed, pseudonyms have been used for the participants, and department disciplines have been grouped under umbrella headings (for example, social sciences or natural sciences).

Each participant was contacted via email and invited to take part. They were also sent a participant information sheet which set out the aims of the project and highlighted key ethical concerns such as informed consent and anonymity. In addition, all interviewees were asked to sign a consent form beforehand agreeing to the interview and for it to be audio recorded. Two participants, one from Hillside and one from Oakbank, did not want their interviews recorded and so hand written notes were taken instead. The interviews were conducted in participants' offices with each lasting on average between one and two hours. The interviews used were semi-structured and based on an interview guide to give direction to the interview (with prompts and probes), but no fixed order of questions. This approach allowed for more flexibility than a structured interview and enabled appropriate probing to occur when deemed necessary by the researcher, a practice which is seen as an essential element of this type of research (Seidman 2006).

I developed the interview guide in stages, and continued to develop the guide throughout the data collection process. Initially, a draft schedule was drawn up. I based the themes for the interview on the study's specific research questions, which link to the underlying theoretical framework described earlier. The research process was "iterative and nonlinear" (Lichtman 2006, p. 15). In other words, in each study, I transcribed and analysed each interview before I undertook the next. This allowed interview questions 
to change as themes and issues emerged from the data and allowed the researcher to reflect deeply on each respondent's interpretations of their experiences (Gilbert 2008).

I analysed the data in two main ways, borrowing techniques from a range of writers (see, for example, Bryman 2008; Charmaz 2006; Lichtman 2006). First, this included reducing the data by using coding and thematic techniques. Second, following Wolcott (1994) who maintains that focused description is at the heart of all qualitative research, I crafted profiles of each participant in line with guidelines outlined by Seidman (2006).

Finally, in order to determine the overall culture and working practices of the case university, and the individual school culture within which each participant worked, data from the interviews were supplemented with web based profiles of each participant and the analysis of key strategic documents produced by the case Universities linked to management culture and working practices. This supplementary data allowed each participant's narrative to be interpreted in context and links to the theoretical framework described earlier in this article.

\section{Findings and Discussion}

In the discussion to follow, I will narrow the focus to three key themes that emerged especially strongly from the data: training and role preparation, managing the workload, and the way forward.

\section{Training and role preparation: a culture of institutional neglect?}

The vast majority of participants from both institutions felt that they had not been properly prepared or supported for taking on the role. For example, fourteen of the 17 respondents from Hillside stated that they had received no formal leadership and management training or preparation for their role. For some of the participants, like 
Hannah and Harry, it was clear from their tone that they were quite annoyed and indignant about this:

Let me see, any formal training? That would be none whatsoever. Let me think, was I offered any? That would be none whatsoever. So I didn't, and haven't ever, received any formal training in management to do the job. (Hannah, 41, Arts and Humanities)

I didn't receive any training at first, no. You're just kind of dropped into it as it were. No training was offered at all. (Harry, 62, Social Sciences)

\begin{abstract}
Alex, who had taken over a department which had gone through a number of recent reorganisations and where staff were feeling quite unsettled, perceived that his lack of induction into the job role had hampered him quite severely in his first few weeks and months in post:
\end{abstract}

\begin{abstract}
There is very little induction into these roles. Nobody works with you to say, "This is what I've done and this is what you might need to look at." The prime example is six months ago, I took on this role and there was no handover file. There was no discussion with the previous incumbent. There was no indication of what needed to be done. It was, "Here you are. Get on with it!" People were either too busy to discuss it or it was just an expectation that we had to get on. So, it was a massive barrier to being effective in the first few months. I kind of wandered around thinking, 'What on earth do I need to do here?' Trying to get information out of people was quite difficult. People had kind of gone into their bunkers over any notion that we might want to change things. (Alex, 53, Social Sciences)
\end{abstract}

This example shows some of the different power plays that are involved in institutions which academic middle managers need to be cognisant of when they take on the position for the first time, and that these are not only played out up and down the organisational chain. For Alex, he found that people in his department were deliberately keeping information from him, so that he could not perform his role properly and 
implement the changes that they were against.

At Oakbank, a more research led institution, eight out of 11 participants stated that that they had no specific training or support before taking on the role, as the following examples show:

But no, I didn't have any specific management experience or training...I had to learn on the job really. (Daniel, 61, Arts and Humanities)

There was no training at all. I discovered everything...It was very difficult. I discovered the problems as they arose. (Fred, 51 Arts and Humanities)

Arguably, it might be reasonable to expect that Hillside (a teaching led, modern university) would have more formal training programmes in place linked to ensuring central accountability and performance (in line with New Public Management ideals) while Oakbank (a traditional, research led institution) would have provided more collegial support opportunities for staff who are taking on the rotated role of academic middle manager for a set period of time. The data suggests, however, that neither of these scenarios were the case. These findings concur with previous research investigating academic management role socialisation (Deem 2000; Eley 1994; Inman 2009; Johnson 2002) and point to the fact that while UK Universities appear to be giving increasing consideration to caring for their student body, especially in the context of rapidly rising student fees following the Browne Report (Browne 2010), this is far from the case for academics who are asked to take on middle management roles in the case study institutions. Indeed, the data here appears to reflect a "culture of institutional neglect" from both institutions - whether traditional or modern in history, and research led or teaching led in nature - a term which has recently been used in relation to narratives of doctoral students' experiencing difficulty with their supervision process (McAlpine et al. 2012, p. 521). 


\section{Managing the workload: a case of the greedy organisation?}

At Hillside, the majority of the 17 respondents identified managing the increasing workload and the resulting lack of time as one of the most challenging aspects of the role. Michelle, who was leading a department where all staff were expected to be research active, felt that it was one of the worst parts of her job. She reflected,

There is too much to do really and keeping it all up in the air is very, very difficult. (Michelle, 49, Natural Sciences)

Similarly, at Oakbank, almost all respondents commented on the sheer volume of work and associated emails that the job created, as the following comments demonstrate:

For me it's difficult that so much of my time is taken up....I used to be able to take my time if I wanted to think about something...but now it is difficult for me to find the time. (Amy, 51, Natural Sciences)

I think the shear workload, particularly with emails and the bureaucracy in terms of the number of forms that need filling out. Because everything is monitored and regulated now across so many areas from health and safety, to quality assurance and teaching, to new program forms and international collaborations...basically, more and more, and everything has a full set of forms that come with it, so I mean that really does wear you down. (Hugh, 42, Social Sciences)

These data suggest that even in a traditional, research led university, where it may be anticipated that there might be more flexible organisational practices in relation to working conditions and accountability procedures, the implications of New Public Management practices are being experienced in similar ways to a more modern, teaching led institution. Indeed, it can be seen from both data sets that one of the key effects of globalisation and the subsequent changing nature of higher education in the case study institutions is workload intensification - manifested in longer hours and increased work effort - which has been linked to the "exploitation, alienation and 
subordination of labour..." (Burchielli et al. 2008, p. 112). As well as taking on substantial leadership and managerial responsibilities, academic department heads in both institutions were on the whole still expected to contribute to teaching and research within the department. In Oakbank, a research led institution, the need to publish and be included in the Research Excellence Framework in 2014 was ever-present. However, even in the teaching led Hillside University, many leaders were still under pressure to publish as the institute strove to change its overall culture to become more research focused in order to compete for international students in an increasingly competitive global market. These findings resonate with the concept of the Greedy Organisation, a concept first proposed by Coser (1974) when discussing institutions such as the Church, political parties and the armed forces. A Greedy Organisation is one that makes "total" claims on their workers (Burchielli et al. 2008) - described in relation to education by Mercer et al. (2010, p. 96):

The Europe-wide experience of increased work intensity over the past 20 years, especially in professional organizations, has encouraged a critical view of so-called greedy organizations. Pressured by fierce competition in global markets, companies are believed to have reduced costs and raised quality by introducing a mix of strategies to increase worker productivity and performance. This has produced a rise in reported work strain and a fall in job satisfaction, especially for professional workers, whose discretion in carrying out daily tasks has been reduced...

If we accept the fact that good leaders are essential for the future success of our higher education institutions (Osseo-Asare et al. 2007; Rowley and Sherman 2003), particularly in such a rapidly changing global HE environment, then we, as a profession, need to combat the notion of greedy organisations (with leadership beings described as particularly "greedy work" (Morley 2013, p. 9)) and provide more time, support and training for today's academic middle managers to allow them to fulfil their duties 
successfully. The data presented here suggest that both teaching led and research led institutions need to support the people in these positions more carefully, and protect their time more, so that those who take on these crucial roles feel valued and that the best may become the sector's effective senior leaders of tomorrow.

\section{The way forward: how would academic middle managers like to be supported?}

In a recent editorial, MacFarlane (2014) contended that although there has been an improvement in the leadership preparation programmes for senior leaders in Higher Education, academics in leadership roles further down the university have in the main been excluded from such opportunities. But what should leadership development programmes look like for academic middle managers? And what are the variances between managing in different types of institutions and departments? Deem et al. (2007) argue that managing academic knowledge work is unique to HE and can cause problems for blanket management approaches and training. This stance links to issues highlighted by Trowler (2008) - who claims that most socialisation and induction occurs at departmental level - and suggests that training and development for academics who become department heads needs to be individualised in relation to the subject area and departmental culture within which they will be working. These arguments are supported by findings from these studies - namely, that for respondents who had received training, individualised training programmes, rather than generic "all must attend" courses, were perceived as far more useful and relevant. Even within the same university, the nature of the department head role differed according to varying school cultures, and the different experiences and skill sets of each academic appointed to department head. Helen, who had come to the Hillside as a head of department from a research-led university, had been expected to attend a range of generic Human Resource training 
courses which, given her skill set and experience, she did not feel was warranted:

Once I arrived, I was bombarded, which is the only word, to the point of irritation with so-called training courses, which was a mystery to me...so nobody had come along and assessed me and said, "We think you need training for this." It was really as if somebody had decided that all staff must have this, without looking at the individual. So I was a little bit reluctant because I couldn't see that there was a match between what they thought I needed and me... So I think it's about relevance. (Helen, 57, Social Sciences)

At Oakbank, those individuals who had received training also felt that it needed to be flexible and "owned" by the individual concerned to ensure that it was relevant.

At the heart of these findings is the ongoing debate about the key purpose of training for such roles, linked to the culture of the institution as espoused and enacted by leaders and managers and staff. Is such training being used by senior managers as a controlling mechanism - to instil and maintain a top down managerial culture, aligning academic middle managers to university processes and ensuring that organisational control is not lost or diluted at departmental level - a practice in line with New Public Management ideology and one which can perpetuate an "us versus them" culture, lead to an erosion of collegiality (Davis et al. 2014), and thus potentially a more divided profession (Deem and Brehony 2005)? Or is it being used as a means of developing and empowering middle leaders to make their own decisions and allow the academics in their departments to develop professionally depending on their individual needs $-\mathrm{a}$ practice in line with more traditional collegial values of higher education? And how can the needs of both the institution and that of the individual academic middle manager be reconciled?

At both institutions, there were examples of leadership development activities that did not appear to be part of any explicit institutional policy and which had 
developed more organically. At Oakbank these included shadowing and learning from people in similar situations, such as experienced department heads working within similar departmental cultures. For example, when Graham was first approached to take on the leadership role, he shadowed the outgoing leader for a year:

So we had a fortnightly meeting together and he would say, "this is what I have done this week and this is what I am going to do." So that was my best bit of preparation. (Graham, 51, Social Sciences)

Similarly, Kevin explained:

I also believe it's important to learn from experienced people...there's nothing more valid than institutional knowledge and people who have gone through a similar situation before. (Kevin, 38, Arts and Humanities)

However, these practices had tended to be set up at the insistence of the incoming department head themselves.

Illustrations of such practices at Hillside were also evident, although again these were not identified as explicit strategic intentions and had been developed more from the "bottom up". For example, ten respondents identified that one of the ways that they had learned to cope with the demands of the job was through informal peer consultation. It was clear from their responses and their tone that this was seen as useful and extremely important. As Maria explained:

I think the other thing that I found useful is meeting with other people in other schools who've got a similar kind of management role and you can learn from their experiences and the kind of approach they take to things and it gives you a wider perspective. (Maria, 59, social sciences)

It appeared that this process allowed for reflection, gave the respondents a sense that they were not alone in their experiences, and allowed them to meet new people and 
improve their social networks.

Another example of "accidental" leadership development practice at Hillside was that ten respondents had gained experience as course leaders before becoming department heads. In these cases, course leaders were responsible for the organisation of the delivery and administration of the courses that they were in charge of, but the position itself was unpaid and had no line management responsibilities, which still remained with the head of department. For many of them, this experience appeared to be a good apprenticeship. David, who was leading a more vocationally orientated department, recalled how he was reluctant to take on this role although he saw it as being a valuable experience:

\footnotetext{
Yes, one of the management roles was a course director role and I think the policy within the department was that it was quite an irksome thing to do and they gave it to the new guy. It was that kind of thing. It wasn't exactly promotion. I took on the role. I was taking my turn. It was interesting and it certainly helps you to get to know the way things work... and I think that on reflection that is very valuable. (David, 54, Social Sciences)
}

The perception from many of the respondents was that a course leader had to work skilfully to get the best out of the people they were working with, even though it was not a paid management position and so they did not have any formal authority over the colleagues they were leading. It also appears that taking on the role of course leader afforded individuals the chance to learn more of the departmental culture of their work place. Thus, it allowed the respondents to learn about the social expectations and standards, signs, language, behaviours, events and people that embody this culture (Fincham and Rhodes 2005).

It was argued earlier that not only is the organisational culture of a university customised at department level (McAleer and McHugh 1994), but that it is generated 
and sustained at this level (Trowler 2008). Consequently, learning about a department's culture allows individuals to learn how to act out roles of self-presentation (Goffman 1959) appropriate to their professional roles, such as the role of department head, and to do so within their particular departmental context. Moreover, it has been suggested that this cultural knowledge can help departmental leaders be more successful in achieving change (Knight and Trowler 2001). Thus, it appears that any support and training for department heads should be devised from the bottom up, with the starting point being the individual academic and department concerned. Learning and developing through the department also shifts the perception of power and control from that of the central university to that of the local context within which the leader will be working and so moves the institution towards a more collegial model of leadership and management practice. Consequently, leadership development activities move away from being seen as a controlling mechanism run by senior academic managers - or by Human Resource departments who are sometimes perceived to have little or no understanding of core academic values and practices - to an on-going programme of development owned by the individual and seen as emancipatory and professionally relevant. In turn, this may allow future senior leaders to subscribe to a set of value systems shared by both managers and academics (Bolden et al. 2012).

\section{Conclusions}

This article has explored how academics who become department heads in two contrasting UK universities are supported in their roles and identified some of the difficulties that they experience. Using a theoretical framework based on the concept of organisational culture, the article has argued that more needs to be done to develop and support academic middle managers in the current higher education environment. While 
it might have been expected that the two case study institutions could have reflected more stark differences in relation to organisational cultures and values surrounding leadership development practices, perhaps with the modern university subscribing more whole heartedly to New Public Management ideologies and the traditional university displaying more collegial traits, the data did not necessarily uphold this view. The evidence presented here seems to show more of a convergence of cultures and value systems between the two institutions, with New Public Ideologies being equally prevalent in each one, albeit in different forms and manifestations, which has leadership development implications for academic middle managers. Such development and support should not be seen as a controlling mechanism in "greedy" organisations, with the key purpose being to increase productivity at the expense of professional academic values and staff motivation. Instead, a more collegial model should be followed, taking the individual and the department as the starting point and basing any support and development on authentic academic value systems. This is not to say that all leadership development activity should be solely individually based, but that any activity should be linked to an individual's leadership needs and specific context if possible, while being balanced with the corporate needs of the institution as a whole.

In the previous section, I argued that if we are to ensure that university middle managers are in a strong position to take on further, more senior, leadership roles within higher education institutions, organisations need to move from a "culture of institutional neglect" to one of support and development for our middle leaders. With this position in mind, the data presented here suggests that much more needs to be done to ensure that academics who take on such roles feel supported and have the necessary leadership and management skills to deal with the highlighted difficulties of the job. It is also clear that while institutions may develop generic training and support for their middle managers 
to cope with increasing externally driven market pressures, customised programmes, tailored to fit the individual and taking into account the differing departmental cultures present in all large higher education organisations, appear to be essential aspects of any such schemes.

It is recognised, of course, that the findings of the two studies discussed here cannot be generalised to all UK higher education institutions. Undeniably, there is a need for more large scale research across a much broader range of higher education institutions to explore how widespread these experiences are. However, if the data is indicative of experiences across the university sector in the UK, it suggests the need for a more strategic and nuanced approach to leadership development in higher education for academic middle managers to ensure the on-going success of our institutions in these ever changing times (Bolden et al. 2008).

\section{References}

Alvesson, M. 2002. Understanding organisational culture. London: Sage Publications Ltd.

Beck, J. and M.F.D. Young. 2005. The assault on the professions and the restructuring of academic and professional identities: A bernsteinian analysis. British Journal of Sociology of Education 26, no 2: 183-97.

Bolden, R., J. Gosling, A. O'brien, K. Peters, M. Ryan and A. Haslam. 2012. Academic leadership: Changing conceptions, identities and experiences in uk higher education. London: Leadership Foundation for Higher Education.

Bolden, R., G. Petrov and J. Gosling. 2008. Developing collective leadership in higher education. In Research and Development Series. London: Leadership Foundation for Higher Education.

Bolton, A. 2000. Managing the academic unit. Milton Keynes: Society for Research in Higher Education and Open University Press.

Browne, J. Independent review of higher education funding \& student finance. http://webarchive.nationalarchives.gov.uk/+/hereview.independent.gov.uk/herev iew/report/.

Bryman, A. 2008. Social research methods. Third ed. Oxford: Oxford University Press.

Bryman, A. 2009. Effective leadership in higher education. London: Leadership Foundation for Higher Education.

Bryman, A. and S. Lilley. 2009. Leadership researchers on leadership in higher education. Leadership 5, no 3: 331-46.

Burchielli, R., T. Bartram and R. Thanacoody. 2008. Work family balance or greedy organizations. Industrial Relations 63, no 1: 108-30. 
Carr, D. 2009. Revisiting the liberal and vocational dimensions of university education. British Journal of Educational Studies 57, no 1: 1-17.

Charmaz, K. 2006. Constructing grounded theory - a practical guide through qualitative analysis. London: Sage.

Coser, L.A. 1974. Greedy institutions : Patterns of undivided commitment. New York: Free Press.

Davis, A., M. Jansen Van Rensburg and P. Venter. 2014. The impact of managerialism on the strategy work of university middle managers. Studies in Higher Education: 1-15.

De Boer, H. and L. Goedegebuure. 2009. The changing nature of the academic deanship. Leadership 5, no 3: 347-64.

Deem, R. 2000. "New managerialism" and the management of uk universities, end of award report on the findings of an economic and social research council funded project oct. 1998-nov.2000. Esrc award number r000 237661: Lancaster University.

Deem, R. and K. Brehony. 2005. Management as ideology: The case of 'new managerialism' in higher education. Oxford Review of Education 31, no 2: 21735.

Deem, R., S. Hillyard and M. Reed. 2007. Knowledge, higher education, and the new managerialism : The changing management of uk universities. Oxford: Oxford University Press.

Eley, A. 1994. Management training for the university head of department. International Journal of Educational Management 8, no 2: 20-22.

Fincham, R. and P. Rhodes. 2005. Principles of organisational behaviour. Fourth ed. Oxford: Oxford University Press.

Floyd, A. 2012. 'Turning points': The personal and professional circumstances that lead academics to become middle managers. Educational Management Administration and Leadership 40, no 2: 272-84.

Floyd, A. 2013. Narrative of academics who become department heads in a uk university. In Academic working lives: Experience, practice and change, eds Gornall, L, Cook, C, Daunton, L, Salisbury, J and Thomas, B, 86-93. London: Bloomsbury.

Floyd, A. and C. Dimmock. 2011. 'Jugglers', 'copers' and 'strugglers': Academics' perceptions of being a hod in a post-1992 uk university and how it influences their future careers. Journal of Higher Education Policy and Management 33, no 4: 387-99.

Gall, M.D., J.P. Gall and W. Borg. 2007. Eduational research - an introduction. Eighth ed. Boston: Pearson.

Gibbs, G., C. Knapper and S. Piccinin. 2009. Departmental leadership of teaching in research-intensive environments. London.

Gilbert, N. 2008. Researching social life. Third ed. London: Sage.

Gmelch, W.H. 2004. The department chair's balancing acts. New Directions for Higher Education, no 126: 69-84.

Gmelch, W.H. and V.D. Miskin. 2011. Department chair leadership skills. Madison, Wisconsin: Atwood Publications.

Goffman, E. 1959. The presentation of self in everyday life St. Ives: Penguin.

Gomm, R. 2009. Key concepts in social science research. Basingstoke: Palgrave Macmillan. 
Henkel, M. 2002. Emerging concepts of academic leadership and their implications for intra-institutional roles and relationships in higher education. European Journal of Education: Research, Development and Policies 37, no 1: 29-41.

Hill, D. and R. Kumar eds. 2009. Global neoliberalism and education and its consequences. Abingdon, Oxon: Routledge.

Inman, M. 2009. Learning to lead: Development for middle-level leaders in higher education in england and wales. Professional Development in Education 35, no 3: 417-32.

Johnson, R. 2002. Learning to manage the university:Tales of training and experience. Higher Education Quarterly 56, no 1: 33-51.

Kezar, A., T. Bertram Gallant and J. Lester. 2011. Everyday people making a difference on college campuses: The tempered grassroots leadership tactics of faculty and staff. Studies in Higher Education 36, no 2: 129-51.

Knight, P. and P. Trowler. 2000. Department-level cultures and the improvement of learning and teaching. Studies in Higher Education 25, no 1: 69-83.

Knight, P. and P. Trowler. 2001. Departmental leadership in higher education. Buckingham: Society for Research in Higher Education and Open University Press.

Kolsaker, A. 2008. Academic professionalism in the managerialist era: A study of english universities. Studies in Higher Education 33, no 5: 513-25.

Lichtman, M. 2006. Qualitative research in education - a user's guide. California: Sage.

Macfarlane, B. 2014. Challenging leaderism. Higher Education Research \& Development 33, no 1: 1-4.

Mcaleer, E. and M. Mchugh. 1994. University departments as professional service firms: Implications for planning and organizing. International Journal of Educational Management 8, no 1: 20-24.

Mcalpine, L., J. Paulson, A. Gonsalves and M. Jazvac-Martek. 2012. 'Untold' doctoral stories: Can we move beyond cultural narratives of neglect? Higher Education Research \& Development 31, no 4: 511-23.

Meek, V.L., L. Goedegebuure, R. Santiago and T. Carvalho eds. 2010. The changing dynamics of higher education middle management. Springer Netherlands.

Mercer, J., B. Barker and R. Bird. 2010. Human resource management in education: Context, themes and impact Abingdon, Oxon: Routledge.

Morley, L. 2013. Women and higher education leadership: Absences and aspirations. London: Leadership Foundation for Higher Education.

Nagy, J. 2011. Scholarship in higher education: Building research capabilities through core business. British Journal of Educational Studies 59, no 3: 303-21.

Nokkala, T. and A. Bladh. 2014. Institutional autonomy and academic freedom in the nordic context [mdash] similarities and differences. High Educ Policy 27, no 1: $1-21$.

Osseo-Asare, A.E., D. Longbottom and P. Chourides. 2007. Managerial leadership for total quality improvement in uk higher education. The TQM Magazine 19, no 6: 541-60.

Owens, R.G. and T.C. Valesky. 2011. Organizational behavior in education. Tenth ed. New Jersey: Pearson.

Parsons, C. and B. Fidler. 2005. A new theory of educational change - punctuated equilibrium: The case of the internationalisation of higher education institutions. British Journal of Educational Studies 53, no 4: 447-65.

Rowley, D. and H. Sherman. 2003. The special challenges of academic leadership. Management Decision 41, no 10: 1058-63. 
Schein, E. 1985. Organizational culture and leadership. San Francisco: Jossey-Bass Ltd.

Seidman, I. 2006. Interviewing as qualitative research - a guide for researchers in education and the social sciences. Third ed. New York: Teachers College Press.

Shaw, M.A., D.W. Chapman and N.L. Rumyantseva. 2013. Organizational culture in the adoption of the bologna process: A study of academic staff at a ukrainian university. Studies in Higher Education 38, no 7: 989-1003.

Shields, R. 2013. Globalization and international education. London: Bloomsbury.

Silver, H. 2003. Does a university have a culture? Studies in Higher Education 28, no 2: 157-69.

Smith, B. 2002. The role of the university head of department - a survey of two british universities. Educational Management and Administration 30, no 3: 293-312.

Smith, B. 2005. Departmental leadership and management in chartered and statutory universities: A case of diversity. Educational Management Administration \& Leadership 33, no 4: 449-64.

Staber, U. 2013. Understanding organizations. London: Sage.

Trede, F., R. Macklin and D. Bridges. 2011. Professional identity development: A review of the higher education literature. Studies in Higher Education 37, no 3: 365-84.

Trowler, P. 2008. Cultures and change in higher education Universities into the 21 st century. Basingstoke: Palgrave Macmillan.

Winter, R. 2009. Academic manager or managed academic? Academic identity schisms in higher education. Journal of Higher Education Policy and Management 31, no 2: 121-31.

Wolcott, H.F. 1994. Transforming qualitative data - description, analysis and interpretation. Thousand Oaks, California: Sage. 